\title{
BODY MASS INDEX AND C-REACTIVE PROTEIN ARE POTENTIAL PREDICTORS OF ASTHMA DEVELOPMENT IN EGYPTIAN POLYCYSTIC OVARY SYNDROME PATIENTS
}

\author{
INDEKS TELESNE MASE I C-REAKTIVNI PROTEIN SU POTENCIJALNI PREDIKTORI RAZVOJA \\ ASTME KOD PACIJENTKINJA SA SINDROMOM POLICISTIČNIH JAJNIKA U EGIPTU
}

\author{
Hebatallah Ahmed Nasser ${ }^{1}$, Nermeen Zakaria Abuel Ezz ${ }^{2}$, \\ Heidi Mohamed Abdel-Mageed ${ }^{3,4}$, Rasha Ali Radwan ${ }^{5}$ \\ ${ }^{1}$ Microbiology \& Public Health Department, Faculty of Pharmacy and Drug Technology, Heliopolis University, \\ Egypt \\ ${ }^{2}$ Biochemistry Department, College of Pharmaceutical Sciences \& Drug Manufacturing, \\ Misr University for Science and Technology, Cairo, Egypt

\begin{abstract}
${ }^{3}$ Biotechnology and Genetic Engineering Division, National Research Center, Cairo, Egypt
${ }^{4}$ Department of Pharmaceutics and Pharmaceutical Technology, Faculty of Pharmaceutical Sciences and Pharmaceutical Industries, Future University in Egypt (FUE), Cairo, Egypt

${ }^{5}$ Biochemistry \& Biotechnology Department, Faculty of Pharmacy \& Drug Technology,
\end{abstract} \\ Heliopolis University, Cairo, Egypt
}

\section{Summary}

Background: Recent studies suggest asthma prevalence in polycystic ovary syndrome (PCOS) patients. This is the first study to explore asthma prevalence among Egyptian PCOS patients. It highlighted common findings in PCOS and asthma. It investigated whether these findings could serve as potential predictors of asthma.

Methods: A hundred PCOS patients, sixty asthmatic patients and thirty apparently healthy females of matched age were included. Body mass index (BMI), C-reactive protein (CRP), IL-6, IgE, $25(\mathrm{OH})$ vitamin $\mathrm{D}$, testosterone and lipid profile were measured.

Results: Both PCOS and asthmatics had significantly higher $\mathrm{BMI}$, Total cholesterol (TC), LDL-C, IgE, CRP and IL-6 $(\mathrm{P}<0.001)$ and lower $25(\mathrm{OH})$ vitamin $\mathrm{D}$ levels $(\mathrm{P}<0.001)$ compared to controls. Within the PCOS group, 47 patients developed asthma with a significant increase in $\mathrm{BMI}$ $(P=0.003), C R P$ and $\mathrm{lgE}$ levels $(P<0.001)$ compared to non-asthmatic PCOS. Both asthmatic PCOS and asthmatics expressed elevated BMI, IgE, IL-6 and CRP levels, but

Address for correspondence:

Rasha Ali Radwan

3 Cairo Belebeis Road

Mobile phone: 002-020-010-020-452-04

Telephone number: 002-024-180-948

Fax number: 002-022-658-812-3

Work number: 002-022-658-812-4

e-mail: rasha.radwan@hu.edu.eg.

\section{Kratak sadržaj}

Uvod: Nedavne studije ukazuju na prevalenciju astme kod pacijentkinja sa sindromom policističnih jajnika (PCOS) Ovo je prva studija koja je istraživala prevalenciju astme među egipatskim PCOS pacijentkinjama i dala je uobičajene nalaze u vezi sa PCOS i astmom. Osim toga, studija je bavi $\mathrm{i}$ istraživanjem da li ovi nalazi mogu poslužiti kao potencijalni prediktori astme.

Metode: Uključeno je 100 pacijentkinja sa PCOS, šezdeset pacijentkinja sa astmom i trideset očigledno zdravih žena odgovarajuće starosti. Izmereni su indeks telesne mase $(\mathrm{BMI}), \mathrm{C}$-reaktivni protein (CRP), IL-6, IgE, $25(\mathrm{OH})$ vitamin $D$, testosteron i lipidni profil

Rezultati: I pacijentkinje sa PCOS i one sa astmom su imale značajno veći $B M I$, ukupni holesterol (TC), LDL-C, lgE, CRP i IL-6 $(P<0,001)$ i niže nivoe vitamina $D(P<0,001)$ $\mathrm{u}$ odnosu na pacijentkinje u kontrolnoj grupi. U okviru PCOS grupe, 47 pacijentkinja je razvilo astmu sa značajnim porastom BMI ( $P=0,003)$, CRP i lgE nivoa $(P<0,001) u$ poređenju sa ne-astmatičnim PCOS. I astmatične pacijen-

List of abbreviations: AUC, Area under curve; BMI, Body mass index; CRP, C-reactive protein; HDL-C, HDL Cholesterol; IgE, immunoglobulin $\mathrm{E} ; \mathrm{IR}$, Insulin resistance; IL, Interleukin; LDLC, LDL-Cholesterol; PCOS, Polycystic ovary syndrome; ROC, Receiver operating characteristic curve; TAG, Triacylglycerol; TC, Total cholesterol. 
with no significant difference between them. Asthmatic PCOS showed significantly higher testosterone and dyslipidemia profile. Multivariate regression revealed that BMI and CRP could predict asthma development within PCOS $(O R=1.104$, C.I 1.004-1.2 and $O R=1, C . I .1-1.02)$, respectively. Receiver operating characteristic (ROC) curve showed that BMI and CRP at a cutoff value $28.5 \mathrm{~kg} / \mathrm{m}^{2}$ and $117.6 \mathrm{nmol} / \mathrm{L}$ respectively could differentiate between asthmatic and non-asthmatic PCOS with sensitivity $63.8 \%$ and specificity $62 \%$ for $\mathrm{BMI}$, and sensitivity and specificity of $66 \%$ for CRP.

Conclusions: This study shows that BMI and CRP are predictors of asthma development in Egyptian PCOS

Keywords: polycystic ovary syndrome, asthma, BMI, IgE, interleukin 6, CRP, dyslipidemia

\section{Introduction}

Polycystic Ovary Syndrome (PCOS) is the most abundant endocrine disorder in females of reproductive age and one of the main causes of infertility with a prevalence of 9-18\% worldwide (1). Reports state that PCOS constitutes a major health issue in Egyptian females $(2,3)$. According to the Rotterdam consensus in 2003, PCOS can be diagnosed by the occurrence of two of the following criteria: Oligoand/or anovulation, clinical and/or biochemical features of hyperandrogenism, and polycystic ovaries on performing ultrasound investigations (4). In addition to infertility, PCOS is associated with several metabolic disorders such as obesity (5), insulin resistance (IR) (6), dyslipidemia (7), increased levels of inflammatory markers, with consequent increased risk of developing Type 2 diabetes and cardiovascular disorders among other serious disorders (7-9).

Meanwhile, asthma is a complex and chronic in ammatory disorder of the airways with local and systemic in ammation. It is characterized by a $\mathrm{T}$ helper cell 2 (Th2)-immune response, resulting in increased total immunoglobulin $\mathrm{E}(\mathrm{lg} \mathrm{E})$, eosinophilia, elevated cytokines, interleukins (IL-4, -5, -13, -1722), tumor necrosis factor-alpha (TNF- $\alpha$ ) and elevated CRP levels $(10,11)$.

Multiple factors contribute to the pathology and severity of asthma attacks, including allergenic inhalation, environmental and immunological factors among others $(12,13)$. Treating asthma depends on both environmental control and strict medication that may be difficult to achieve. Consequently, asthma remains to be a chronic, recurrent health problem which requires better management and preventive protocols.

Recent studies are pointing out the higher prevalence of asthma in PCOS patients compared to normal females (14-16), which increases the need to study the common findings of both PCOS and asthma and explore the factors that contribute to such prevalence. tkinje sa PCOS i one bez PCOS su imale povišene nivoe BMI, IgE, IL-6 i CRP, ali bez značajne razlike između njih. Astmatične PCOS pacijentkinje su pokazale značajno veći testosteronski i dislipidemijski profil. Multivarijantna regresija je pokazala da BMI i CRP mogu predvideti razvoj astme unutar PCOS grupe $(O R=1,104, C . I$ 1,004-1,2 i OR=1, C.I. 1-1,02), respektivno. ROC kriva je pokazala da se BMI i CRP kod graničnih vrednosti $28,5 \mathrm{~kg} / \mathrm{m}^{2}$ i $117,6 \mathrm{nmol} / \mathrm{L}$ mogu razlikovati između astmatičnih i neastmatičnih PCOS sa osetljivošću $63,8 \%$ i specifičnošću $62 \%$ za BMI, dok je osetljivost i specifičnost za CRP $66 \%$.

Zaključak: Ova studija pokazuje da su BMI i CRP prediktori razvoja astme kod pacijentkinja sa sindromom policističnih jajnika u Egiptu

Ključne reči: sindrom policističnih jajnika, astma, BMI, lgE, interleukin 6, CRP, dislipidemija

Obesity has been linked to both PCOS and asthma, whereas abnormal lipid profile is a well-known characteristic of PCOS patients (17). High levels of triacylglycerols (TAG), total cholesterol (TC) and LDLcholesterol (LDL-C), lower HDL-cholesterol (HDL-C) together with elevated body mass index (BMI) are continuously reported in PCOS cases as compared to healthy matches $(18,19)$. Moreover, epidemiological studies have linked the presence of obesity and asthma (20-22). However, to date, no previous data was available about asthma in Egyptian PCOS patients and the effect of BMI and dyslipidemia on this relation.

In addition to obesity and dyslipidemia, nearly $67-85 \%$ of the PCOS patients are reported to suffer from $25(\mathrm{OH})$ vitamin D deficiency, where Vitamin D is a crucial physiological player in follicular development, sensitivity to follicular stimulating hormone and Anti-Müllerian hormone (AMH) signalling (23). Furthermore, multiple studies have investigated the possible link between $25(\mathrm{OH})$ vitamin $D$ deficiency and asthma (24). However, no sufficient data is available whether $25(\mathrm{OH})$ vitamin D level can play a role in asthma development within PCOS patients. In line with the documented inflammatory nature of asthma, PCOS is also reported to be accompanied by an inflammatory condition, where increased levels of cytokines, IL-18, CRP, IL- 6 and its receptor gene have lately been linked to the pathogenesis of both disorders $(8,11)$. Yet again, limited data is available about the inflammatory markers in asthmatic PCOS patients.

To date and the best of our knowledge, there are very few community-based studies that explored the relationship between asthma and PCOS $(14,15)$. Furthermore, no previous study investigated the coprevalence of asthma and PCOS in the Egyptian population, nor it studied the findings and biochemical parameters of both diseases.

Taking these facts into consideration, in this cross-sectional study, we aimed firstly to explore the 
prevalence of asthma in Egyptian PCOS patients. Secondly, to investigate the common findings and biomarkers shared by both disorders. Finally, we aimed at detecting whether any of such common findings could serve as potential predictors of asthma development within PCOS patients.

\section{Materials and Methods}

\section{Study population}

The present cross-sectional study included 3 main groups. First, Group 1 comprised 100 PCOS patients aged from 21 to 29 years old with primary or secondary infertility, it was called PCOS group. The PCOS group was further divided into 2 subgroups. Subgroup 1 included 47 patients diagnosed with both PCOS \& asthma, called asthmatic PCOS. Subgroup 2 included 53 patients diagnosed with PCOS only, called non-asthmatic PCOS. The diagnosis of PCOS was made according to Rotterdam consensus. Thereby, two out of the three following conditions were required to confirm the diagnosis of PCOS: Oligo- and/or anovulation (defined by the presence of oligomenorrhea or amenorrhea), clinical and/or biochemical features of hyperandrogenism (defined by having clinical hirsutism (Ferriman-Gallaway score

6 ), acne or alopecia and/or elevated androgens) and polycystic ovaries on ultrasound examination (3). Asthma diagnosis was based on both clinical examination and spirometry together with eosinophilia and increased IgE level (25).

Second, Group 2 comprised 30 apparently healthy females aged from 21 to 29 set as the control group. All control females were healthy and had regular cycles ranging from 25 to 35 days and had neither ovarian gynecological disorders nor endocrinal abnormalities. In addition, they were not suffering from bronchial asthma or allergic rhinitis. Third, Group 3 included 60 female asthmatic patients of matched age (22-28) were set as asthmatics group. Group 2 and 3 were collectively called non-PCOS group $(N=90)$. All subjects were recruited from the outpatient clinics of Al-Azhar University Teaching Hospitals all over Egypt. Subjects having Cushing's syndrome, androgen-secreting tumors, congenital adrenal hyperplasia, diabetes, immunological diseases, any form of malignancy and hyperprolactinemia were excluded from the study. No cases included in the study were smokers nor received oral contraceptive drugs. All subjects had stable body weight for at least 3 months. The study was performed after obtaining informed consent from all subjects and the approval of the ethics committee and the Review Board at Al-Azhar University, Cairo, Egypt in accordance with The Code of Ethics of the Declaration of Helsinki.

\section{Laboratory Procedure}

In the present investigation, all blood samples were taken at a specified day of the menstrual cycle. Weight and height were measured on the same day of blood sampling and used to calculate BMI. Sera were separated, and samples were stored at $-80{ }^{\circ} \mathrm{C}$ until the time of analysis. Serum total testosterone was measured by immunoassay (Architect 2nd Generation, Abbott Diagnostics, and USA). $25(\mathrm{OH})$ vitamin $D$ was measured using DRG $25(\mathrm{OH})$ vitamin D (total) ELISA (DRG Instruments GmbH, Germany). Serum IL-6 was measured using Human Interleukin 6 (IL-6) ELISA Kit (My BioSource, USA). Total IgE was measured using The Elecsys IgE II immunoassay (Roche Diagnostics, USA). CRP levels were measured using Tina-quant C-reactive protein Gen.3 (Roche Diagnostics, USA). TAG, TC and HDL-C were determined using enzymatic spectrophotometric assay (Diamond Diagnostics, D-P international, Egypt). LDL-C was calculated from TAG and HDL-C values using the Friedewald's formula (26):

$$
\text { LDL-C }=\text { Total C }-[(T A G / 5)+\text { HDL-C }] \text { (1) }
$$

\section{Statistical analysis}

In the current investigation, differences in variables between different groups of the study population were assessed using the Mann-Whitney test. Continuous data were presented as a median and interquartile range. Categorical data were presented as percentages. Multivariable regression analysis was done to detect the presence of possible predictors of asthma within the PCOS group. Factors included in the model were selected based on identifying the measured clinical variables of possible prognostic importance for the outcome in question (Asthma). To explore the ability of the selected markers measured to differentiate between asthmatic and non-asthmatic patients in the PCOS group, Receiver operating characteristic (ROC) curve was used. The area under the curve (AUC) was calculated. The yield values were from 0.5 (no predictive power) to 1.0 (perfect prediction). The optimal cut-off was determined using Yoden's Index: maximum [sensitivity - (1-specificity)] (27). For all data, a P value of $<0.05$ (two-tailed) was considered significant. All statistical analyses were performed using the SPSS package (version 23 for Windows; SPSS Inc., Chicago, IL, USA).

\section{Results}

Comparing different variables in PCOS and asthmatic groups vs control

In the present investigation, both PCOS (Group 1) and asthmatic (Group 3) groups showed significantly higher BMI, TC, LDL-C and higher inflammato- 
Table I Comparison between different variables in PCOS vs. controls, and Asthmatic patients vs. controls respectively. Data are presented as median and interquartile range. *indicates significant difference at $\mathrm{P}<0.05$.

\begin{tabular}{|c|c|c|c|c|c|}
\hline Parameters & $\begin{array}{c}\text { PCOS } \\
(N=100)\end{array}$ & $P$ value & $\begin{array}{l}\text { Controls } \\
(\mathrm{N}=30)\end{array}$ & $\begin{array}{l}\text { Asthmatic } \\
(\mathrm{N}=60)\end{array}$ & $P$ value \\
\hline $\lg E(\mu \mathrm{g} / \mathrm{L})$ & $342(177.6-1110)^{*}$ & $<0.001^{*}$ & $54(40.8-62.4)$ & $1162.4(1083-1281)^{*}$ & $<0.001 *$ \\
\hline Age (years) & $26(21-29)$ & 0.67 & $25(23-29)$ & $25(22-28)$ & 0.28 \\
\hline $\operatorname{BMI}\left(\mathrm{kg} / \mathrm{m}^{2}\right)$ & $\begin{array}{c}28.53 \\
(27.2-34.1)^{*}\end{array}$ & $<0.001^{*}$ & 23.34 (21.6-26.9) & $31.6(28.3-33.46)^{*}$ & $<0.001^{*}$ \\
\hline $\begin{array}{l}25(\mathrm{OH}) \\
\text { vitamin } \mathrm{D}(\mathrm{nmol} / \mathrm{L})\end{array}$ & $36.5(19.4-44.22)^{*}$ & $<0.001^{*}$ & $81.5(66.4-100)$ & $31.9(28.3-33.46)^{*}$ & $<0.001^{*}$ \\
\hline $\begin{array}{l}\text { Total Testosterone } \\
(\mathrm{nmol} / \mathrm{L})\end{array}$ & $4.7(4.3-5)^{*}$ & $<0.001^{*}$ & $0.7(0.45-1.1)$ & $0.76(0.35-1.1)$ & 0.9 \\
\hline $\mathrm{TC}(\mathrm{mmol} / \mathrm{L})$ & $6.47(6.1-6.88)^{*}$ & $<0.001^{*}$ & $4.6(4.35-5.3)$ & $5.1(4.6-5.8)^{*}$ & $<0.001^{*}$ \\
\hline LDL-C (mmol/L) & $4.68(4.4-5.2)^{*}$ & $<0.001^{*}$ & $2.9(2.5-3.4)$ & $3.2(2.9-4.2)^{*}$ & $<0.001^{*}$ \\
\hline $\mathrm{HDL}-\mathrm{C}(\mathrm{mmol} / \mathrm{L})$ & $0.99(0.85-1.1)^{*}$ & $<0.001^{*}$ & $1.1(1.1-1.8)$ & $1.03(0.88-1.11)$ & 0.2 \\
\hline TAG (mmol/L) & $1.42(1.07-1.86)$ & 0.2 & $1.17(1.13-1.8)$ & $1.4(1.26-1.8)$ & 0.1 \\
\hline IL-6 (nmol/L) & $\begin{array}{c}0.0015 \\
(0.0013-0.0017)^{*}\end{array}$ & $<0.001^{*}$ & $\begin{array}{c}0.00021 \\
(0.0002-0.00025) \\
\end{array}$ & $\begin{array}{c}0.0017 \\
(0.0014-0.0018)^{*}\end{array}$ & $<0.001^{*}$ \\
\hline CRP (nmol/L) & $\begin{array}{c}114.28 \\
(102.85-180.95)^{*}\end{array}$ & $<0.001^{*}$ & $57.1(38-76.19)$ & $\begin{array}{c}146.4 \\
(130-180.95)^{*}\end{array}$ & $<0.001 *$ \\
\hline
\end{tabular}

Table II Comparison between different parameters in PCOS vs non-PCOS cohort. (Collectively healthy controls and asthmatic non-PCOS). Data are presented as a median and interquartile range. ${ }^{*}$ indicates a significant difference at $\mathrm{P}<0.05$.

\begin{tabular}{|c|c|c|c|}
\hline Parameters & $\begin{array}{c}\text { PCOS (Group 1) } \\
(\mathrm{N}=100) \\
\text { (Asthmatic PCO =47, } \\
\text { Non Asthmatic PCOS=53) }\end{array}$ & $\begin{array}{c}\text { Non PCOS cohort } \\
(\mathrm{N}=90) \\
\text { Controls }=30(\text { Group 2), } \\
\text { Asthmatics }=60(\text { Group 3) }\end{array}$ & $P$ value \\
\hline $\operatorname{lgE} \mu \mathrm{g} / \mathrm{L}$ & 342 (177.6-1110) & $1086(61.8-1190)$ & 0.26 \\
\hline Age (years) & $26(21-29)$ & $25(23-28)$ & 0.81 \\
\hline BMI $\left(\mathrm{kg} / \mathrm{m}^{2}\right)$ & $28.53(27.2-34.1)$ & $28.8(24.7-32.9)$ & 0.32 \\
\hline $25(\mathrm{OH})$ vitamin $\mathrm{D}(\mathrm{nmol} / \mathrm{L})$ & $36.5(19.4-44.22)$ & $37.44(29.44-68.5)$ & $0.01 *$ \\
\hline Total Testosterone(nmol/L) & $4.7(4.3-5)$ & $0.72(0.35-1.1)$ & $<0.001 *$ \\
\hline $\mathrm{TC}(\mathrm{mmol} / \mathrm{L})$ & $6.47(6.1-6.88)$ & $4.85(4.61-5.8)$ & $<0.001 *$ \\
\hline LDL-C (mmol/L) & $4.68(4.4-5.2)$ & $3.2(2.8-4.12)$ & $<0.001 *$ \\
\hline $\mathrm{HDL}-\mathrm{C}(\mathrm{mmol} / \mathrm{L})$ & $0.99(0.85-1.1)$ & $1.08(0.93-1.11)$ & 0.12 \\
\hline TAG (mmol/L) & $1.42(1.07-1.86)$ & $1.55(1.2-1.8)$ & 0.3 \\
\hline IL-6 (nmol/L) & $0.0015(0.0013-0.0017)$ & $0.0014(0.0002-0.0018)$ & $0.016^{*}$ \\
\hline CRP (nmol/L) & 114.28 (102.85-180.95) & $130(76.19-160)$ & 0.6 \\
\hline
\end{tabular}


Table III Comparison between different variables between non-asthmatic PCOS and asthmatic PCOS (Columns 1 \& 3) and comparing different variables between asthmatic PCOS and asthmatic patients (Columns 3 \& 4). Data are presented as a median and interquartile range. *indicates a significant difference at $\mathrm{P}<0.05$.

\begin{tabular}{|l|c|c|c|c|c|}
\hline Parameters & $\begin{array}{c}\text { Non-asthmatic } \\
P C O S(N=53)\end{array}$ & P value & $\begin{array}{c}\text { Asthmatic PCOS } \\
(\mathrm{N}=47)\end{array}$ & Asthmatic (N=60) & P value \\
\hline IgE $(\mu \mathrm{g} / \mathrm{L})$ & $\begin{array}{c}183.6 \\
(92.4-269.04)\end{array}$ & $<0.001^{*}$ & $\begin{array}{c}1176 \\
(816-1276)\end{array}$ & $\begin{array}{c}1162.4 \\
(1083-1281)\end{array}$ & 0.23 \\
\hline Age (years) & $26(22-29)$ & 0.39 & $26(21-28)$ & $25(22-28)$ & 0.95 \\
\hline BMI (kg/m²) & $28(24.6-30.16)$ & $0.003^{*}$ & $29.7(28.3-35.6)$ & $\begin{array}{c}31.6 \\
(28.3-33.46)\end{array}$ & 0.84 \\
\hline $\begin{array}{l}25(\mathrm{OH}) \text { vitamin D } \\
(\mathrm{nmol} / \mathrm{L})\end{array}$ & $\begin{array}{c}36.5 \\
(17.09-41.17)\end{array}$ & 0.08 & $\begin{array}{c}337.44 \\
(22.46-51.417)\end{array}$ & $\begin{array}{c}31.9 \\
(28.3-33.46)\end{array}$ & 0.067 \\
\hline $\begin{array}{l}\text { Total Testosterone } \\
(\mathrm{nmol} / \mathrm{L})\end{array}$ & $4.7(4.5-5.1)$ & 0.052 & $4.67(3.9-5.1)$ & $0.76(0.35-1.1)$ & $<0.001^{*}$ \\
\hline TC (mmol/L) & $6.34(6.07-6.9)$ & 0.43 & $6.47(6.14-7)$ & $5.1(4.6-5.8)$ & $<0.001^{*}$ \\
\hline LDL-C (mmol/L) & $4.66(4.44-5.21)$ & 0.8 & $4.8(4.4-5.23)$ & $3.2(2.9-4.2)$ & $<0.001^{*}$ \\
\hline HDL-C (mmol/L) & $1.03(0.87-1.13)$ & 0.17 & $0.95(0.82-1.1)$ & $1.03(0.88-1.11)$ & 0.2 \\
\hline TAG (mmol/L) & $1.35(1.01-1.8)$ & 0.2 & $1.53(1.2-1.88)$ & $1.4(1.26-1.8)$ & 0.3 \\
\hline IL-6 (nmol/L & $\begin{array}{c}0.0015 \\
(0.0014-0.002)\end{array}$ & 0.15 & $\begin{array}{c}0.0015 \\
(0.0012-0.0017)\end{array}$ & $\begin{array}{c}0.0017 \\
(0.0014-0.0018)\end{array}$ & 0.12 \\
\hline CRP (nmol/L) & $\begin{array}{c}109.5 \\
(72.38-128.6)\end{array}$ & $<0.001 *$ & $\begin{array}{c}142.86 \\
(104.76-200)\end{array}$ & $\begin{array}{c}146.4 \\
(130-180.95)\end{array}$ & 0.6 \\
\hline
\end{tabular}

Table IV Multivariable regression analysis model, to detect the predictors of asthma within PCOS patients. All factors that previously exhibited $\mathrm{P}<0.1$ within the two subgroups of PCOS patients were included in the model. Regression analysis confirmed that only BMI and CRP levels maintained their significance as predictors of asthma at $P<0.05$. (Denoted by *).

\begin{tabular}{|l|c|c|c|c|}
\hline \multirow{2}{*}{ Parameters } & \multirow{2}{*}{ OR } & \multirow{2}{*}{ P-value } & \multicolumn{2}{|c|}{ 95\% C. I. } \\
\cline { 4 - 5 } & & & Lower & Upper \\
\hline BMI & 1.104 & $0.041^{*}$ & 1.004 & 1.213 \\
\hline CRP & 1.010 & $0.014^{*}$ & 1.002 & 1.07 \\
\hline $25(\mathrm{OH})$ vitamin D & 1.031 & 0.61 & 0.999 & 1.064 \\
\hline Total Testosterone & 0.68 & 0.23 & 0.36 & 1.3 \\
\hline
\end{tabular}

ry markers as IgE, IL-6 and CRP levels $(P<0.001)$ and lower $25(\mathrm{OH})$ vitamin $D$ levels $(P<0.001)$ compared to controls (Group 2). On the other hand, only the PCOS group (Group 1) showed significantly higher total testosterone levels $(P<0.001)$ and lower HDL-C $(P<0.001)$ compared to controls (Group 2). In contrast, there was no significant difference in age, and TAG levels compared to controls (Group 2) as shown in (Table I).
Comparing different variables in the PCOS group vs non-PCOS cohort

We investigated the difference in the detected physical and biochemical parameters between PCOS patients and the non-PCOS cohort which included both healthy controls and asthmatic patients (Groups $2 \& 3$ collectively) $(\mathrm{N}=90)$. PCOS patients (Group 1) showed significantly higher total testosterone, TC and LDL-C levels $(P<0.001)$ and lower $25(\mathrm{OH})$ vitamin $D$ levels as compared to the non-PCOS cohort. On the other hand, there was no significant difference in age, BMI and TAG levels between both cohorts as shown in (Table II). 
Comparing different variables in asthmatic PCOS vs non-asthmatic PCOS

Within the PCOS group, asthmatic PCOS patients showed significantly higher IgE level $(P<0.001)$, BMI $(P=0.003)$ and $C R P$ level $(P<0.001)$ compared to the non-asthmatic PCOS patients. Meanwhile, there was no significant difference between both groups concerning total testosterone, $25(\mathrm{OH})$ vitamin $\mathrm{D}$ levels and lipid profile parameters. Detailed data are shown in (Table III).

Comparing different variables in asthmatic PCOS vs asthmatic patients

In the present investigation, asthmatic PCOS patients (Subgroup 1) showed significantly higher total testosterone level $(P<0.001), T C$ and LDL-C levels $(P<0.001)$ as compared to asthmatic patients (Group 3). On the other hand, there was no significant difference between the two groups concerning $B M I$, vitamin D, HDL-C and TAG levels. Both asthmatic PCOS and asthmatic patients shared a common increase in BMI, IgE, IL-6 and CRP levels with no significant difference between the two groups as shown in (Table III).

\section{Multivariable regression analysis}

Within the PCOS group (Group 1), it was found that asthmatic patients (Subgroup 1) had significantly higher $\mathrm{BMI}, \mathrm{IgE}$ and CRP levels $(\mathrm{P}<0.05)$ as compared to non-asthmatic PCOS patients (Subgroup 2). For further exploration for these variables as possible predictors of asthma in PCOS patients, multivariable regression analysis was done. Moreover, factors exhibiting $\mathrm{P}<0.1$ were also included in the model (25 $(\mathrm{OH})$ vitamin $\mathrm{D}$ and total testosterone). As IgE was already used as a diagnostic factor for asthma in combination with clinical symptoms, it was not included in the multivariable regression analysis.

Results showed that the significant relationship between BMI, CRP levels and asthma was maintained in the multivariable regression analysis. Both $\mathrm{BMI}$ and CRP were significant predictors of asthma within the $P C O S$ group $(O R=1.104, C . I 1.004-1.2$ and $O R=1$, C.I. 1-1.02), respectively as shown in (Table III).

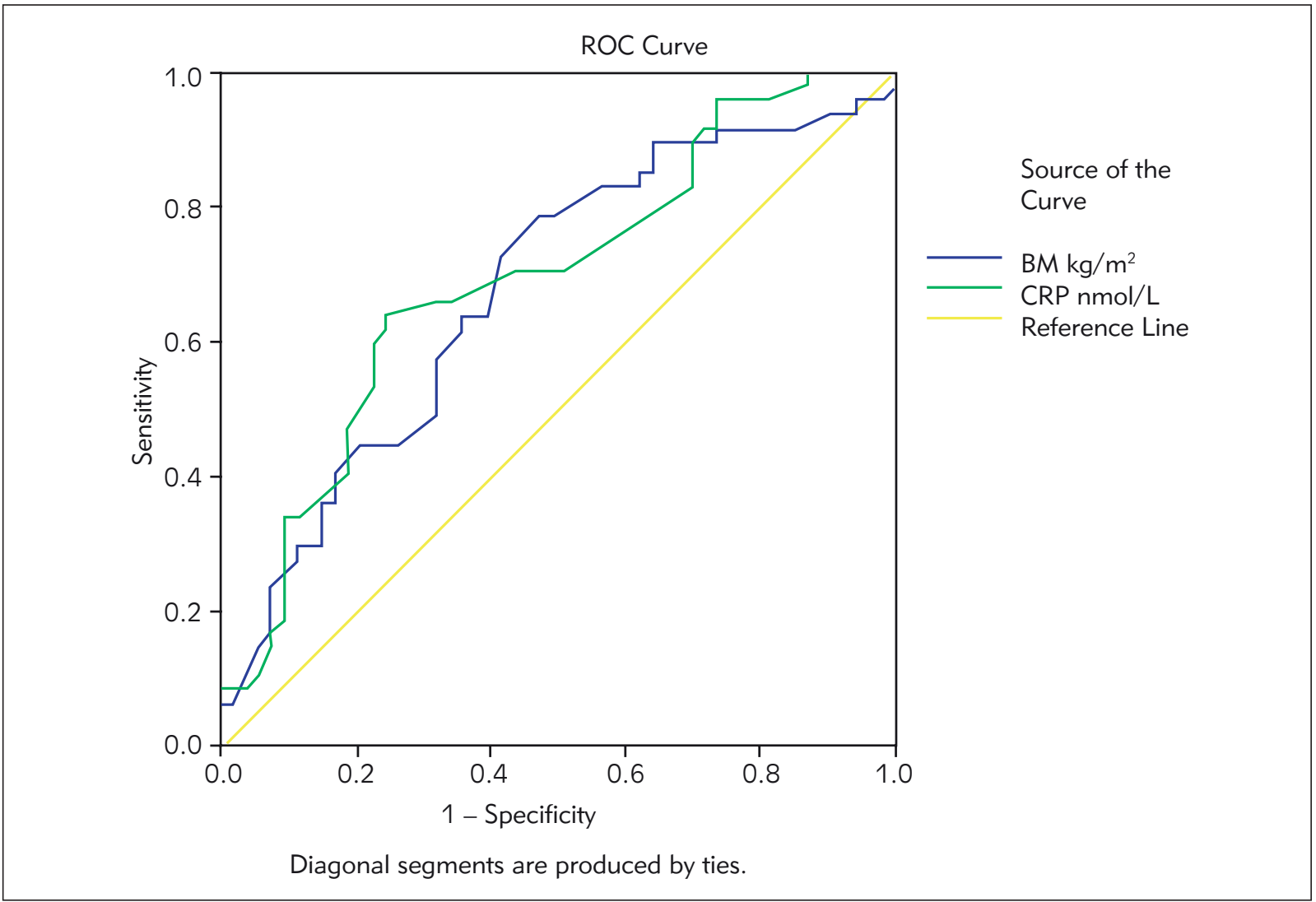

Figure $1 \mathrm{ROC}$ curve illustrating the potential of $\mathrm{BMI}$ and CRP to differentiate between asthmatic and non-asthmatic PCOS patients. At area under the curve (AUC=0.67, $\mathrm{P}=0.003$ ), the optimal cutoff value for $\mathrm{BMI}$ is $28.5 \mathrm{~kg} / \mathrm{m} 2$ with sensitivity $63.8 \%$ and specificity $62 \%$, whereas the optimal cutoff value of CRP level is $117.6 \mathrm{nmol} / \mathrm{L}$ with sensitivity and specificity $66 \%$ at $(\mathrm{AUC}=$ $0.69, P=0.001$.) 


\section{Receiver operating characteristic curve}

To further explore the potential of BMI and CRP to differentiate between asthmatic (Subgroup 1) and non-asthmatic PCOS (Subgroup 2) patients, the ROC curve was done on all 100 patients in Group 1. ROC curve showed that both BMI and CRP has a diagnostic ability to detect asthma in PCOS patients with an area under the curve (AUC=0.67 and 0.69, $P$ value $=0.003,0.001$ ) respectively. A cutoff value of BMI $28.5 \mathrm{~kg} / \mathrm{m}^{2}$ can detect asthma with a sensitivity of $63.8 \%$ and specificity $62 \%$, whereas a cutoff value of CRP $117.6 \mathrm{nmol} / \mathrm{L}$ can detect asthma within PCOS group with sensitivity and specificity $66 \%$ as illustrated in Figure (1).

\section{Discussion}

Up to date, there have been no communitybased studies that investigated the association between PCOS and asthma, especially in relation to the common findings of both disorders. Hence, in this study, we aimed to explore the common biomarkers of PCOS and asthma in Egyptian PCOS patients, and we investigated the possible potential of these factors as predictors for asthma development.

We examined the BMI and a panel of metabolic, hormonal and inflammatory markers in PCOS patients versus age-matched healthy controls and asthmatic female patients.

Upon comparing PCOS patients to non-PCOS cases, we found that PCOS patients had significantly higher total testosterone, higher TC, and LDL-C together with significantly low levels of $25(\mathrm{OH})$ vitamin D. The same profile was maintained upon comparing asthmatic PCOS patients to asthmatic patients with no PCOS. Such results are in accordance with previous studies $(3,17,28)$ and they confirm the main findings of PCOS, where dyslipidemia is highly prevalent in PCOS even in lean females mostly due to insulin resistance (29). Whereas vitamin D deficiency has also been reported in PCOS patients (30), contributing to their disturbed metabolic profile.

On examining the findings of both disorders, we found that both PCOS and asthmatic patients had significantly higher BMI, TC, and LDL-C as compared to healthy controls. This goes in agreement with previous studies that link PCOS and asthma to obesity and associated dyslipidemia, where both PCOS and asthma are reported to worsen by obesity and improve by weight loss $(17,31,32)$.

Our findings also showed that both PCOS and asthmatic patients suffered from significantly low levels of $25(\mathrm{OH})$ vitamin $\mathrm{D}$ as compared to controls. Decreased levels of $25(\mathrm{OH})$ vitamin $D$ have been linked to increased risk of asthma attacks in asthmatic patients $(23,24,28)$. Additionally, Vitamin D deficiency is known to be highly prevalent in PCOS patients (67-85\%), where the deficiency is especially reported to worsen the symptoms of PCOS (29), including menstrual irregularities, cardiac disorders (33), obesity $(34,35)$ and deteriorating metabolic phenotype (36).

Concerning the inflammatory markers, asthmatic patients showed significantly higher inflammatory markers levels against healthy controls. Similarly, PCOS patients had significantly higher IL-6, CRP and $\mathrm{lgE}$ levels as compared to controls. However, the asthmatic group expectedly showed higher inflammatory marker levels in comparison with the PCOS group. PCOS is associated with low-grade systemic in ammation which elevates biomarkers such as CRP, IL-18, monocyte chemoattractant protein-1, and leucocytes (37), especially when accompanied by obesity (3840). Moreover, the increased levels of IL-6 and its receptor gene have lately been linked to the pathogenesis of PCOS and asthma, with recommendations for further investigations to explore the clinical significance of IL-6 in both disorders $(40,41)$.

To get more understanding of asthma development and prevalence in PCOS patients, we classified PCOS patients in our study to asthmatic and nonasthmatic PCOS subgroups and analyzed their BMI, metabolic, hormonal and inflammatory profiles. Within the PCOS group, 47 out of 100 PCOS patients (47\%) developed asthma. This finding confirms our hypothesis and agrees with previous reports that show a high prevalence of asthma within PCOS patients in different populations (22). Glintborg and colleagues (14) reported the elevated prevalence of asthma and higher use of asthma drugs (19.2\% vs 14.1\%; $\mathrm{p}<0.001)$ in PCOS females against non-PCOS females in the Danish population. Similarly, a retrospective study in Australian women with and without PCOS showed that PCOS women were more frequently hospitalized for asthma as compared to nonPCOS females (10.6\% vs 4.5\%, p<0.001) (15). Both the Danish and Australian studies did not report detailed data on the BMI or metabolic profiles of the recruited cases. Here, it is worth mentioning that to the best of our knowledge, our study is the first report to assess asthmatic and non-asthmatic PCOS patients concerning their metabolic, hormonal and inflammatory markers.

Within the PCOS group, we found that asthmatic PCOS patients had significantly higher BMI, IgE and CRP levels as compared to the non-asthmatic PCOS patients whereas no significant difference appeared between the two subgroups in terms of the measured hormonal or lipid profile. This correlates with the fact that $\mathrm{IgE}$ is one of the characteristic biological markers of asthma (42) and sheds more light on the probable role of CRP in the pathogenesis of asthma.

Furthermore, upon comparing asthmatic PCOS patients to asthmatic patients with no PCOS, we 
found that both populations shared high BMI, inflammatory markers levels and low $25(\mathrm{OH})$ vitamin $D$ level with no significant difference between them, which support the assumption that some or all of these factors contribute to asthma development. In accordance, it is documented that asthmatic women have a trend of higher BMI in PCOS and non-PCOS cases $(20,21)$. Thaw et al. (22) showed that asthmatic PCOS patients had a trend for a higher BMI compared with non-asthmatic PCOS patients $(29.9 \pm 0.9$ versus $27.7 \pm 0.4 \mathrm{~kg} / \mathrm{m}^{2}$ ). Moreover, recent studies relate obesity to a higher incidence of asthma even after exclusion of smoking and chronic obstructive pulmonary disease (COPD) cases $(11,22,43)$.

Whereas the mechanism linking obesity and asthma is still unclear, it can be attributed to the enhanced inflammation present in cases of obesity that may trigger airway inflammation $(20,21,44)$. Taking this into consideration, and since PCOS is widely characterized by obesity, we suggest that the elevated $\mathrm{BMI}$ and the accompanying inflammation (represented here in high CRP, IgE and IL-6) in PCOS cases may contribute further to airway inflammation and consequent high incidence of asthma in PCOS females.

To explore how far these factors can actually affect asthma development within the PCOS population, multivariable regression was performed, and it confirmed the ability of both elevated BMI and CRP levels to act as predictors of asthma development within PCOS patients $(O R=1.104, C . I$ 1.004-1.2 and $\mathrm{OR}=1$, C.I. 1-1.02), respectively. Contrarily, none of the other parameters as testosterone level, vitamin D or IL-6 showed a prognostic ability to predict asthma among PCOS patients. These results are in agreement with our hypothesis that obesity in PCOS might provoke mild inflammation that can furtherly increase air passage inflammation and asthma incidence. Meanwhile, the inability of disturbed vitamin D and IL-6 levels to predict asthma among PCOS patients needs to be confirmed with studies on different populations.

In order to determine the optimal cutoff values, ROC curve for both BMI and CRP level within PCOS patients showed that BMI higher than $28.5 \mathrm{~kg} / \mathrm{m}^{2}$

\section{References}

1. March WA, Moore VM, Willson KJ, Phillips DI, Norman RJ, Davies MJ. The prevalence of polycystic ovary syndrome in a community sample assessed under contrasting diagnostic criteria. Hum Reprod 2010; 25: 544-51.

2. Sanad AS. Prevalence of polycystic ovary syndrome among fertile and infertile women in Minia Governorate, Egypt. Int J Gynaecol Obstet 2014; 125: 81-2.

3. Bakeer E, Radwan R, El Mandoury A, Abd El Rahman A, Gad M, Abd El Maksoud S. Anti-müllerian hormone as a can differentiate between asthmatic and non-asthmatic PCOS patients with a sensitivity and specificity of $63.8 \%$ and $62 \%$, while CRP of higher than 117.6 $\mathrm{nmol} / \mathrm{L}$ can differentiate asthmatic and non-asthmatic PCOS with both sensitivity and specificity of $66 \%$. Even though poor accuracy of these parameters remains to be a limitation, yet the proved prognostic ability of BMI and CRP level can present an aiding tool for better management of asthma within PCOS patients, and can be further confirmed or improved with more studies on larger populations.

There is an increasing demand for precision medicine and management of heavy burden diseases as asthma. Consequently, studies for strategic prevention or earlier control of asthma are highly required, especially in complicated cases like PCOS. This study presents a better understanding of the prevalence and common findings of asthma within Egyptian PCOS where elevated BMI and CRP levels showed their ability to predict asthma development among PCOS patients.

The limitations in this study were the relatively small population and the inability to monitor the patients on the long term to examine the effect of controlling BMI and CRP changes. Further larger population studies, with trials to control these two parameters among other characteristics are encouraged, in the hope of better management of asthma occurrence or severity of attacks within PCOS patients.

Acknowledgements. All authors would like to thank Engy Bakeer (MSc), Faculty of Pharmacy, German University in Cairo (Post affiliation) for helping in sample collection. All authors would like to extend their sincere gratitude to Abdullah A. Abd El Rahman (MSc) Obstetrics \& Gynecology Department, Faculty of Medicine, Al-Azhar University, Cairo, Egypt and Hossam Mohamed (PhD) Chest Department, Faculty of Medicine, Al-Azhar University, Cairo, Egypt for diagnosis and recruitment of subjects.

\section{Conflict of interest statement}

The authors stated that they have no conflicts of interest regarding the publication of this article.

diagnostic marker in Egyptian Infertile polycystic ovary syndrome females: correlations with vitamin D, total testosterone, dyslipidemia and anthropometric parameters. J Med Biochem 2018; 37: 448-55.

4. Rotterdam EA. Revised 2003 consensus on diagnostic criteria and long-term health risks related to polycystic ovary syndrome. Fertil Steril 2004; 81(1): 19-25.

5. Bentley-Lewis R, Seely E, Dunaif A. Ovarian hypertension: polycystic ovary syndrome. EndocrinolMetabClin North Am 2011; 40: 433-49. 
6. Diamanti-Kandarakis E, Dunaif A. Insulin resistancpolycystic ovary syndrome revisited: an update on mecand implications. Endocr Rev 2012; 33: 981-1030.

7. Daan NMP, Koster MPH, de Wilde MA, Dalmeijer G W, Evelein, A M V, Fauser BCJM.et al. Biomarker Profiles in Women with PCOS and PCOS Offspring; A Pilot Study. PLoS ONE 2016.

8. Perović Blagojević I, Ignjatović S, Macut Dj, KoturStevuljević J, Božić-Antić I, Vekić J, Bjekić-Macut J, Kastratović-Kotlica B, Andrić Z, Ilić D. Evaluation of a summary score for dyslipidemia, oxidative stress and inflammation (the doi score) in women with polycystic ovary syndrome and its relationship with obesity. J Med Biochem 2018; 37: 476-85.

9. Baldani DP, Skrgatic L, Ougouag R. Polycystic Ovary Syndrome: Important Underrecognised Cardiometabolic Risk Factor in Reproductive-Age Women. International Journal of Endocrinology 2015; 2015.

10. Collinson P. Laboratory medicine is faced with the evolution of medical practice. J Med Biochem 2017; 36: 2115.

11. Haldar P, Pavord ID, Shaw DE, Berry MA, Thomas $M$, Brightling $C E$, et al. Cluster analysis and clinical asthma phenotypes. Am J Respir Crit Care Med 2008; 178: $218 \mathrm{e} 222$.

12. Beasley R, Semprini A, Mitchell EA. Risk factors for asthma: is prevention possible? Lancet 2015; 386: 107585.

13. Toskala E, Kennedy DW. Asthma risk factors. Int Forum Allergy Rhinol 2015; 5: S11-S16.

14. Glintborg D, Hass Rubin K, Nybo M, Abrahamsen $B$, Andersen M. Morbidity and medicine prescriptions in a nationwide Danish population of patients diagnosed with polycystic ovary syndrome. Eur J Endocrinol 2015; 172: 627-38

15. Hart R, Doherty DA. The potential implications of a PCOS diagnosis on a woman's long -term health using data linkage. J Clin Endocrinol Metab 2015; 100: 911-9.

16. Zierau L, Gade EJ, Lindenberg J, Backer V, Thomsen SF. Coexistence of asthma and polycystic ovary syndrome: A concise review. Respiratory Medicine 2016; 119: $155 \mathrm{e} 159$.

17. Kandarakis D, Papavassiliou, AG, Kandarakis, SA, Chrousos GP. Pathophysiology and types of dyslipidemia in PCOS. Trends in Endocrinology \& Metabolism 2007: Trends in Endocrinology \& Metabolism.

18. Wild RA, Rizzo M, Clifton S, Carmina EX. Lipid levels in polycystic ovary syndrome: systematic review and metaanalysis. Fertil Steril 2011; 95: 1073-9.

19. Kim JJ, Choi YM. Dyslipidemia in women with polycystic ovary syndrome. Obstetrics \& Gynecology Science 2013; 56: 137-42.

20. Sutherland ER. Linking obesity and asthma. Ann NY Acad Sci 2014; 1311: 31-41.

21. Weiss ST. Obesity: insight into the origins of asthma. Nat Immunol 2005; 6: 537-9.
22. Thaw D, Htet HJ, Teede BD, Loxton D, Real FG, Moran $\sqcup$, et al. Asthma in reproductive-aged women with polycystic ovary syndrome and association with obesity. European Respiratory Journal 2017; 49.

23. Thomson RL, Spedding S, Buckley JD. Vitamin D in the aetiology and management of polycystic ovary syndrome. Clin Endocrinol (Oxf) 2012; 77: 343-50.

24. Esfandiar N, Alaei F, Fallah S, Delara Babaie, Niloofar Sedghi. Vitamin $D$ deficiency and its impact on asthma severity in asthmatic children. Italian Journal of Pediatrics 2016; 42: 108

25. Dati F, Ringel KP. Reference values for serum $\operatorname{lgE}$ in healthy non-atopic children and adults. Clin Chem 1982; 28: 1556.

26. Fukuyama N, Homma K, Wakana N, Kudo K, Suyama A, Ohazama $H$, et al. Validation of the Friedewald Equation for Evaluation of Plasma LDL-Cholesterol. J Clin Biochem Nutr 2008; 43: 1-5.

27. Perkins NJ, Schisterman EF. The Inconsistency of „Optimal« Cutpoints Obtained using Two Criteria based on the Receiver Operating Characteristic Curve. Am J Epidemiol 2006; 163: 670-5.

28. Lim SS, Davies MJ, Norman RJ, Moran L. Overweight, obesity and central obesity in women with polycystic ovary syndrome: a systematic review and meta-analysis. Hum Reprod Update 2012; 18: 618-37.

29. Radwan RA, Abuelezz NZ, Abdelraouf SM, Bakeer EM, Abd El Rahman A. Decreased serum level of gammaaminobutyric acid in Egyptian infertile females with polycystic ovary syndrome is correlated with dyslipidemia, total testosterone and $25(\mathrm{OH})$ vitamin D levels. Journal of Medical Biochemistry 2019; 10.2478/jomb-2018-0051.

30. Krul-Poel YHM, Koenders PP, Steegers-Theunissen RP, ten Boekel E, Wee MMt, Louwers $Y$, et al. Vitamin D and metabolic disturbances in polycystic ovary syndrome (PCOS): A cross-sectional study. PLoS ONE 2018; 13(12): e0204748. 10.1371/journal.pone.0204748

31. Khan UI, Rastogi D, Isasi CR, Coupey SM. Independent and synergistic associations of asthma and obesity with systemic in ammation in adolescents. J Asthma 2012; 49:1044e1050.

32. Adeyeye OO, Ogbera AO, Ogunleye OO, Brodie-Mens AT, Abolarinwa FF, Bamisile RT et al. Understanding asthma and the metabolic syndrome, a Nigerian report. Int Arch Med 2012; 5: 20.

33. Lin $M-W, W u M-H$. The role of vitamin $D$ in polycystic ovary syndrome. The Indian Journal of Medical Research 2015; 142: 238-40.

34. Zittermann A. Vitamin D in preventive medicine: are we ignoring the evidence? Br J Nutr 2003; 89: 552-72.

35. Wehr E, Pilz S, Schweighofer N, Giuliani A, Kopera D, Pieber TR, et al. Association of hypovitaminosis D with metabolic disturbances in polycystic ovary syndrome. Eur J Endocrinol 2009; 161: 575-82.

36. Krul-Poel Y, Snackey C, Louwers Y, Lips P, Lambalk $\mathrm{CB}$, Laven JS, et al. The role of vitamin $\mathrm{D}$ in metabolic disturbances in polycystic ovary syndrome: A systematic review. Eur J Endocrinol 2013; 169: 853-65. 
37. Hefler-Frischmuth K, Walch K, Huebl W, Baumuehlner K, Tempfer C, Hefler L. Serologic markers of autoimmunity in women with polycystic ovary syndrome. Fertil Steril 2010; 93: 2291-4.

38. Barthelmess EK, Naz RK. Polycystic ovary syndrome: current status and future perspective. Frontiers in bioscience (Elite edition). 2014; 6: 104-19.

39. Randeva HS, Tan BK, Weickert MO, Lois K, Nestler JE, Sattar N, et al. Cardiometabolic aspects of the polycystic ovary syndrome. Endocrine Reviews 2012; 33: 812-41.

40. Escobar-Morreale HF, Luque-Ramírez M, González F. Circulating inflammatory markers in polycystic ovary syndrome: a systematic review and meta-analysis. Fertility and Sterility 2011; 95: 1048.e1042-1058.e1042.
41. Poynter ME, Irvin CG. Interleukin-6 as a biomarker for asthma: hype or is there something else? Eur Respir J 2016; 48: 979-81.

42. Godar M, Blanchetot C, de Haard H, Lambrecht BN, Brusselle G. Personalized medicine with biologics for severe type 2 asthma: current status and prospects. mAbs 2017; 10: 34-45.

43. Zein JG, Yaqoob Z, Al-Kindi SG, DeBoer M, Teague W $\mathrm{G}$, Gaston BM, et al. Polycystic ovary syndrome is associated with higher risk for asthma. Presented at: American Thoracic Society (ATS) 2017 International Conference; Washington, DC. Abstract A1307. 2017.

44. Avci E, Avci AG, Important biomarkers that play a role in the chronic obstructive pulmonary disease process. J Med Biochem 2018; 37; 46-53. 